\title{
Values Education and its Implications on Guidance and Counselling
}

\begin{abstract}
This paper looks at Values Education and its implications on Guidance and Counseling, as well as its recommendation for use in the Colleges of Education in Ghana. It considers the classification, methods, theoretical framework, advantages, and disadvantages of values education. The Psychoanalytic and behavioural theories were used to explain the link and effects of people's past experiences and those of the present experiences. It further examines the values counsellors and counsellees are expected to develop and exhibit, and its implications on Guidance and Counseling services. Published books, articles, and personal observation during teaching and counseling services provided the main sources of information. The study brings to the fore the fact that values education serves as a preparatory ground for effective Guidance and Counseling Services to take place in educational institutions. It is therefore recommended that educators be exposed to values education and be encouraged to teach values that are associated with their courses. This is vital to lay a good foundation for counsellors and counsellees for effective counseling services to go on in the Colleges of Education in Ghana.
\end{abstract}

Keywords: Values Education, Guidance and Counselling, Colleges of Education, Counsellors

\section{INTRODUCTION}

In this study 'values' means principles or standards of behaviour; one's judgment of what is important in life. Values in this instance are associated with some rightness or wrongness. The use of 'values' in this work is synonymous with the concepts: moral principles, ethics, moral code, moral values, moral standards, code of behaviours, rules of conduct, and standards of behaviours. That is, 'values' is used in this study in a generic sense to mean the above words or phrases. Many writers have done some work on nature, the etymology of values, methods for the teaching of values as well as the importance of values education. ${ }^{2}$ However, it seems not much work has been done on values education, its implications on Guidance, and Counselling in Ghana. Asare-Danso and Arthur did some work on Values education but did not thoroughly discuss the implications of Values Education on Guidance and Counselling. ${ }^{3}$ If values education is important in our educational system, what are its implications for Guidance and Counselling in our schools and Colleges of Education?

With this background, this study seeks to examine the various classifications of values, the various methods used for teaching values, as well as some of the theories that are associated with values education. The merits and demerits of values education are also discussed. Particular attention is given to training values counsellors and counsellees are to acquire to make counseling effective. The study finally highlights Values Education, its implications on Guidance and Counselling Services in schools and colleges.

\footnotetext{
H. C. Ganguli, G. P. Mehrotra, \& H. D. Mehlinger, "Values, Moral Education and Social Studies," In UNESCO Handbook for the Teaching of Social Studies, (1981), Edited by Harward D. Mehlinger. Paris: UNESCO.

3 Seth Asare-Danso. Values are religious phenomena, (Cape Coast: YACI Publishing House. (2015):66.
} 


\section{Classification of Values}

Values can be classified into many forms. Ganguli, Mehrotra \& Mehlinger, ${ }^{4}$ classified values according to their nature and benefits that one expects from them. According to them, values may be classified as follows:

Category of values
Religious (Spiritual)
Moral
Political
Economic
Social
Intellectual
Professional
Aesthetic
Sentimental
Material

\section{Category of values}

Moral

itical

\author{
Examples of values \\ piety, obedience, authority \\ honesty, gratitude, respect \\ probity, accountability, justice \\ productivity, efficiency \\ courtesy, commitment, hospitality \\ intelligence, clarity \\ success, diligence, skilfulness \\ beauty, symmetry \\ Love, acceptance \\ Physical health, safety, comfort
}

The category of values mentioned above forms part of the types of values taught in Colleges of Education in Ghana. These include various courses such as Religious and Moral Education, Guidance and Counselling, among others. ${ }^{5}$

\section{Methods of Teaching Values}

Traditionally, there are some methods and approaches used for the teaching of values. Some of these approaches include; persuasion, limiting choices, setting rules and regulations, presenting doctrines, and appealing to conscience among others. ${ }^{6}$ Analytically, all these mentioned methods of teaching values are externally imposed and do not give room for making choices. Proponents of modern approaches to values education are Superka, Ahrens \& Hedstrom and Huitt. They proposed five basic approaches to teaching values. They are as follows: ${ }^{7}$

A. Inculcation (having students incorporate the standards and norms of his/her referent cluster or society primarily through modeling, rewards, and sanctions).

B. Moral Development (having students move through the stages of moral reasoning based on higher sets of values, make use of primary discussions of "moral dilemmas")

C. Analysis (helping students use a rational, scientific investigation to decide on issues of values and ethics, often using case studies).

D. Values Clarification (helping students determine their own and others' values, often with role-playing, games or simulations as well as discussions and self-analysis)

E. Action Learning (using values clarification and/or different approaches, providing students with opportunities to practice values with social action).

According to Lickona, all of these approaches are necessary, but none is sufficient, to instill lifelong adherence to high principles. ${ }^{8}$ Good values/character education must draw from each of the approaches above: Schools must help children understand core values, adopt or commit to them, and then act upon them in their own lives. ${ }^{9}$

\section{Theoretical Framework}

\section{Psychoanalytic Theory}

The Psychoanalytic theory is used to explain the link and effects of people's past experiences and that of the present experiences. Freud believed that by attempting to reach and examine the hidden aspects of our souls, we can now see these aspects and understand the roles they play in our lives..$^{10}$ Psychoanalysis is based on acquiring an understanding of one's unconscious conflicts and reworking or reconstructing their effects on the individual. ${ }^{11}$

The theory assumes that in man's mind, nothing happens by chance or at random. An Individual's behaviour is

\footnotetext{
H. C. Ganguli, G. P. Mehrotra, \& H. D. Mehlinger, , "Values, Moral Education and Social Studies,"

H. C. Ganguli, G. P. Mehrotra, \& H. D. Mehlinger, , "Values, Moral Education and Social Studies,"

L. E. Raths, M. Harmin, \& S. B. Simon, Values and Teaching. Columbus, Ohio: MerrillPublishing Co. (1966):. 24.

D. Superka, C. Ahrens \& J. Hedstrom. The values education life sourcebook. New York: Longman., (1976). :78.

Thomas Lickona, "The return of character education". NY: Bantam Doubleday. (1993). 54.

Thomas Lickona, "The return of character education". 54.

10 Sigmund Freud, Psychoanalytic theory. London: Hogarth Press. (1961). 120.

11 Ibid.
} 
determined by intrapersonal factors. All behaviour of man has meaning if we can only have sufficient insight to identify and understand it. Present behaviour is determined by previous behaviour and biological drives. It is based on the idea that past experiences have a bearing on experiences and feelings in the present, and that, important relationships, perhaps from early childhood, maybe replayed with other people later in life. Basically, psychoanalysis holds that: The key to understanding human behaviour is to understand the unconscious. The understanding of man is based on the psychology of conflict. ${ }^{12}$

\section{Strengths of the Psychoanalytic Theory}

1. Four of the strengths are explained below through the theory, people are now aware that the emotions adults generate, whether good or bad can affect the moral development of children;

2. Also, the theory has established the need for teachers and adults to give proper attention to children;

3. From the theory, it is clear that people exhibit some irrational level of the rule because such people had their development impeded during the early years of their lives. Thus, experiences and difficulties during a particular childhood stage may produce specific sorts of idiosyncrasies in adults' personalities which teachers and adults must be aware of;

4. Some early life experiences such as irrational child-rearing techniques can inhibit proper moral development. ${ }^{13}$

Despite numerous strengths of the psychoanalytic theory, there are some criticisms leveled against the theory. Three of the criticisms are mentioned as follows: It lacks scientific data to support the theory. It lacks definitive evidence which shows that the personality is structured and operates as indicated by Freud. Again, it is difficult to predict how certain developmental difficulties will be displayed in the adult. Also, cross-cultural research raises questions about the universality of Freud's view of personality development. ${ }^{14}$

The connection between the psychoanalytic theory and this study is that learners' acquisition of values and attitudes have something to do with their past experiences. The psychoanalytic theory puts forward that a person's past experiences have a bearing on experiences and feelings in the present, and that, important relationships, perhaps from early childhood, may be replayed in the person's life later in life. This suggests that the past experiences of learners can be explored to help develop their attitudes towards the acquisition of values in Colleges of Education. When learners can find the link and balance between their past and the present experiences, it will enable them to live a more productive life.

\section{The Behavioural Theory}

Skinner contends that behaviour can be modified or changed through the use of reinforcement techniques such as rewards, punishments modeling ${ }^{15}$. He was interested in changing behaviour through conditioning. Skinner explains the acquisition of behaviour by three mechanisms namely, positive reinforcement and rewards, punishment, or the threat of it as well as modeling (imitation). Thus he focused on how classical and operant conditioning affected behaviour. In his view, agents of socialization include adults and peers. Skinner further stressed that all categories of people accept rewards and punishment as a way of reinforcing and checking behaviours. This is so because good behaviours merit rewards and bad behaviours deserve punishment.

Operant conditioning requires that the participant be actively involved. This type of learning involves rewarding the desired behaviour or punishing the undesired behaviour until the person learns to discriminate the desired behaviour that elicits the reward. Operant conditioning differs from respondent conditioning in that operant conditioning is the conditioning of voluntary responses through rewards or reinforcement. Social modeling is the process where new behaviour is learned from watching other people and events without experiencing the consequences of the behaviour or engaging in the behaviour. Some of the strengths of the behavioural theory are as follows: it can be inferred from the theory that models from the print and electronic media can have a great impact on the moral behaviour of children. Moreover, the theory explains why some people often show inconsistencies in their conduct or behaviour from one occasion to another. Also, the difference in behaviour of people may be explained in terms of the different ways people are brought up. For example, teachers can use rewards, punishment, or modeling as a means of shaping the moral character of their students. ${ }^{16}$

\footnotetext{
12 Ibid., 121.

13 Seth Asare-Danso, Values are religious phenomena. 28-43.

14 Seth Asare-Danso, Charles Nyarko Annobil, Owusu Afriyie and Mary Agyemang. Religious \& Moral Education: for Colleges of Education 1, Kumasi: Jerusalem Press. (2016). 132.

15 Barrhus Frederick Skinner, Behavioural Theory. 143.

16 Seth Asare-Danso, Values are religious phenomena. 28-43.
} 
Asare Danso contends that there are some weaknesses associated with the Skinner behavioural theory. ${ }^{17}$ The theory places more emphasis on only conduct (behaviour) without referring to moral feelings or moral reasoning (judgment). It is difficult to test the theory in the real sense of the world because even children with very similar backgrounds do not behave in the same way. Again, the theory seeks to present children as passive learners who only react to the influenced of other people rather than learning from what they consider to be ideal. ${ }^{18}$

The link between the behavioural theory by Skinner and the present paper is that learners' attitudes towards values education in Colleges of Education and universities depend upon their behaviour pattern. The behavioural theory provides a framework for understanding how the learners from higher institutions of learning behave in certain ways or develop bad or good attitudes towards the acquisition of values. The behavioural theory postulates that acquisition of behaviour is influence by three mechanisms namely, positive reinforcement and rewards, punishment, or the threat of it as well as modeling. ${ }^{19}$ This presupposes that the attitudes of learners in the Colleges of Education and universities towards the acquisition of values can be influenced by the use of positive reinforcements, in other words, the application of motivational techniques to help to develop their attitudes and values. In the light of counseling, the behavioural counselor's roles vary and include being a consultant, a reinforcer, and a facilitator to the clients who are the students and pupils.

Another perspective of the behavioural theory that drives the paper is the use of modeling techniques proposed by Skinner as a means of changing behaviour through observation. ${ }^{20}$ This implies that moral educators from the Colleges of Education and universities can use modeling as one of the teaching techniques for teaching values in the basic schools. Counselors and Guidance Coordinators using social learning may model the desired behaviour for the clients to imitate.

\section{Merits and Demerits of Values Education}

It is for the merits that character and values education is regarded as the first and foremost goal of education by some educationists including Power and Dewey. ${ }^{21}$ Authors such as Sockett, Ayers, and Noddings regard education as a moral activity. ${ }^{22}$

Arthur posits that values are the most valuable gifts which a person can have and experience. These experiences may develop certain general guides to behaviour. These guides have a propensity to provide direction to life and maybe called values. Our values demonstrate what we tend to do with our life as well as our energy. Having values affects a person's behaviour. Values are important because they serve as criteria for the selection of actions in a situation. ${ }^{23}$

According to Debbarma, human values have been a central concept in the social sciences since their inception. Human values play a vital role in society, for they are said to be the basis of human beings for leading a better life. It is believed that all holy books of all religions contain the values of a good life. The significance of values is commonly cited concerning the global and national problems, whether it is in debates in international assemblies, in studies criticizing "value-free" approaches to research, or in the discussion of value of life and individual fulfillment. Thus, values are considered mainly important in questions of cultural development and are central to concern for the preservation of cultural heritage. ${ }^{24}$

Again, Debbarma noted that it is to be mentioned that the importance of human values is seen right from the childhood of a person. Pre-school is the first stage or period that lays the foundation of information on human values. Because information about the values of life is a continuous process found in society. Nonetheless, the initial information not only obtains in earlier periods that begin and end in the period to adolescence but also continues personality. From now on, there can be changes in these values, but basic values have been developed. Changing a child's wrong behaviour is more difficult than trying to develop new behaviour. It is critical to developing the child's personality in a planned and systematic process to prevent the wrong development of values education. ${ }^{25}$

According to Arthur, values are important because they serve as criteria for the selection of actions in a situation. When most explicit and fully conceptualized, values become criteria for judgment, preferences, and choice. Values are principles, qualities, or objects that someone identifies as having intrinsic worth. Values give direction and consistency to behaviour; help us to know what to do and not to make time for. Values establish a relationship between the world

18 Ibid.

19 Barrhus Frederick Skinner, Behavioural Theory. New York: Appleton. (1975).143.

20 Barrhus Frederick Skinner, Behavioural Theory. 144.

21 John Dewey, Philosophy of education. New York: Horace Liveright. (1934) .88.

22 E. L. Ayers,. Ethics in education. London: Prentice-Hall. (2009). 54.

23 M.. Arthur, Happiness, morality, and freedom. New York: Brill Publications. (2014). 124.

24 M. Debbarma, Importance of human values in the society. International Journal of English language, Literature, and Humanities. (2014).10: 193-223.

25 M. Debbarma, Importance of human values in the society. International Journal of English language, Literature, and Humanities. (2014). 10: 193-223. 
and ourselves. Values set the direction for one's life. ${ }^{26}$

Values are general principles that guide actions. Values are not actions; they are the codes, which underlie the sanctions or punishments for some choices of behaviour and rewards for others. Values are also seen as a list of criteria by which behaviour is judged and consequences called upon. ${ }^{27}$

The experts' ideas given above indicate that values play a very important role in the life of every individual and society as a whole. Because values guide human actions and inactions enabling us to relate well with one another.

\title{
Demerits
}

Writers, who disagree with values education mostly pose the question, which values? Should we allow values to be taught in school? The question is as sensible as asking whether our bodies should be allowed to contain bacteria. Just as humans are teeming with microorganisms, so are schools teeming with values. Whether or not we deliberately adopt a character or moral education programme, we are always teaching values. Even people who insist that they are conflicting to values in school usually mean that they are opposed to values other than their own. And that raises the unavoidable question: Which values, or whose, should be taught? Therefore, Colleges of Education can vigorously and unapologetically set about teaching all of those values. ${ }^{28}$

\section{The implication of Values Education on Guidance and Counselling}

This section discusses how Values Education and Guidance and Counselling are integrated into helping the individual to develop a holistic and integrated personality.

\section{Education and Guidance}

The role education plays in individuals' lives is enormous. However, the effect of education upon an individual depends upon the efficacy and the wisdom with which one separates and determines life purposes and goals. Kankam and Onivehu argued that if education can help the individual develop his/her potentiality then its orientation, direction, and functions need careful definition. ${ }^{29}$ According to them, education generally performs three main functions, which include: Developmental, Differentiating, and Integrating. Values education as an aspect of general education also performs these three functions. ${ }^{30}$

\section{Developmental functions}

One of the main functions of Education is to help individuals to unearth their unique qualities through the development of their values, skills in vocational ventures, and social adjustment. It is through education that individuals get the advantage to enlarge their wellbeing, aptitudes, and values. Unquestionably, individuals cannot develop their values without understanding themselves and the aggregate of their environments. This makes it crucial to assist individuals to clarify their life goals and purposes so that they can face challenges in life with confidence. Individuals with their attitudes and personal values developed can respond appropriately to any change - social, economic, and political with the skills developed. Guidance and its services focus on individuals and the decisions they make in life. The guidance makes sure that individuals develop their personalities in such a way that their social, moral, psychological among others to work together in harmony for the betterment of the individual. Finally, Guidance also sees to it that the principle of individual differences is put into practice in the processes of education. There is the need to step up values education for it to impact positively on personal and social Guidance and Counselling services in the Colleges of Education and other higher institutions of learning. This will help the students to understand the aggregate of their environment to guide them to make intelligent choices that are well informed so that they can lead a qualitative and a well-behaved life. The goal of behaviorist counselors like other theories here is to improve the life of the client through better adjustments to life and to achieve personal goals professionally and personally.

Another developmental function of values education is that it inculcates into counsellors and counsellors expected values for effective and efficient guidance and counselling activities to go on. Below are examples of the class of values counsellors and counselees develops:

\author{
Category of values Examples of values \\ Moral honesty, gratitude, respect \\ Social courtesy, commitment, hospitality \\ 26 M. Arthur, Happiness, morality, and freedom. New York: Brill Publications. (2014). 34. \\ 27 M. Arthur, Happiness, morality, and freedom. (2014). .34 \\ 28 W, Huitt, Values: Educational Psychology Interactive. 78. \\ 29 George Kankam, \& A. O. Onivehu. Principles and Practices and Practices of Guidance and Counseling. Accra: Accra Press. (2000). 49-50 \\ 30 George Kankam, \& A. O. Onivehu. Principles and Practices and Practices of Guidance and Counseling
}


Intellectual

Professional

intelligence, clarity

Sentimental

success, diligence, skillfulness, confidentiality

Love, acceptance

Moreover, a study conducted by Adinkrah in Colleges of Education indicated from the findings that pre-service teachers in the Colleges of Education are relatively younger than it was in recent times. The majority (71\%) of the pre-service teachers' age bracket falls within $18-24$ years according to the findings. ${ }^{31}$

This information calls for collaborative teamwork among values educators who are to teach and help develop their students' values during contact hours to lay a good foundation for Guidance and Counselling Co-ordinators in schools and colleges for their work to be easier. This practice conforms with one of the moral education lessons in Kohlberg's theory which says that educators' understanding of students' behaviour is a necessary tool every teacher needs for effective teaching and learning. ${ }^{32}$

\section{Differentiating Functions}

Every individual has his/her capabilities, interest, and goals in life and these differences distinguish one individual from the other. These differences call for specialized programmes to be embarked upon to help every individual to meet their special needs. To meet the varied needs of all students at the lecture hall is difficult since educational programmes cannot enable all students to achieve specific goals with equal success. It is, therefore, imperative for the individual to seek detailed knowledge to understand himself or herself through values clarification in values education. One of the characteristics of the Guidance programmes in education is to assist students to acquire knowledge about themselves and come to terms with their experiences. This aspect of Guidance enables students to make life meaningful for themselves as they can clarify their aims and purposes in life. This implies that values education and orientation in Guidance activities in the Colleges of Education in Ghana must be stepped-up, especially the information services aspect of Guidance and counselling. Information provided must be integrated within the interest and personality of the students. It is appropriate to add that information service is more than information giving. ${ }^{33}$

Values clarification approach to the teaching of values is found to be one of the most effective and modern ways of teaching values. Values clarification approaches are quite similar to principles used in counseling because of the learner or client-centered approach in both recognition of the dignity, worth, and uniqueness of the client used in both situations. Religious and Moral Education, using the values clarification approach can help learners to understand and appreciate their uniqueness or how they differ from others. By so doing, values clarification fulfills one of the purposes of Guidance and Counseling. In support of this assertion, Sigmund Freud in his "Theory psychoanalysis" argues that moral educators' understanding of the differences in their students' behaviour puts them in a better position to help correct those who are deviant. ${ }^{34}$

This knowledge in values clarification will help the counselor to effectively use appropriate teaching and learning materials during counseling of students. Again, Counselors with good skills could help learners to transfer their previous knowledge in values clarification to go through the counseling processes effectively.

\section{Integration Function}

One of the main functions of values education is to groom students to be integrated into the cultural settings of society. For society to be able to strive on unity and togetherness with fewer conflicts depends largely on a common understanding of attitudes, values, and beliefs of the people. Values Education builds in students, common basic shared beliefs, attitudes, and values. Guidance programmes help students to understand themselves and their social environment better to enable them to put into practice, the sense of shared attitudes and values of society. Guidance inculcates in students the need for showing respect and upholding the dignity of the individual's way of thinking, behaving, and interests to ensure harmony and co-existence.

The finding that past experiences influence the values and attitudes of learners has its implications on counseling. Two of the educational implications of the psychoanalytic theory of Sigmund Freud states that meaningful learning experiences must be provided because what children go through in life can be impacted negatively or positively on their

\footnotetext{
31 Bernard Kofi.. Adinkrah, Pre-Service Teachers' Attitudes' towards the Teaching of Values in the Colleges of Education in the Eastern Region of Ghana. Unpublished PhD Dissertation. University of Education, (2018). Winneba. Faculty of Educational Studies, Department of Psychology

32 L. Kohlberg, Stages and Sequence: The Cognitive-developmental approach to socialization.” In D. A. Goslin (Ed.), Handbook of Socialization Theory and research, (1969), (347 - 380). Chicago: Rand Mcnally.

33 George Kankam, \& A. O. Onivehu, Principles and Practices and Practices of Guidance and Counseling. 49-50.

34 Sigmund Freud, .Psychoanalytic theory. 121.
} 
moral development. ${ }^{35}$

Counselors can rely on and use the relevant previous knowledge of students in values education to help learners to understand themselves and the world around them. Counselors can also use the values educators, both at home and school in team counseling to help learners to fit into their society.

Moreover, one of the purposes of Guidance and Counselling is to plan and develop suitable programmes and curriculum needs of students. This purpose provides reliable information upon which suitable school programmes are designed to meet the peculiar needs of students. ${ }^{36}$

Many factors influence learners' attitudes and values formation. The outstanding ones are education, religion, guidance, and past experiences. With this reliable information, Guidance and Counselling Co-ordinators can be equipped to design and plan colleges' and universities' curriculum based on learners' experiences to meet the peculiar needs of learners. This implication enforces the point made by Goldman in his theory "The Child's Religious Thinking". Educators' attention was drawn to the fact that in teaching, he/she should begin from the things children often see and wonder about and not what is perceived as the content they need to know at their level. ${ }^{37}$

For this reason, it is advisable for moral educators to listen to children, recount their experiences, and gradually help them to appreciate the deeper content of their experiences.

\section{CONCLUSION}

The paper has looked at values education and its implications on Guidance and Counselling. The analysis of values education concerning its classification, theories, merits, and demerits has shown that values education has some implications on guidance and counseling with regards to individuals and groups' developmental, differentiating, and integrating themselves into their environment as well as fitting well into their society. For this reason, values educators in the Colleges of Education in Ghana should be encouraged to help lay a good foundation for guidance and counseling activities. This is to enable learners to develop both individual and societal values to help them differentiate between individual capabilities and weaknesses as well as integrate themselves into their society and fit into the world around them better.

\section{BIBLIOGRAPHY}

Adinkrah, B. K. Pre-Service Teachers' Attitudes' towards the Teaching of Values in the Colleges of Education in the Eastern Region of Ghana. Unpublished PhD Dissertation. University of Education, Winneba. Faculty of Educational Studies, Department of Psychology. (2018).

Arthur, M. Happiness, morality, and freedom. New York: Brill Publications. (2014).

Asare-Danso, S., Values are religious phenomena. Cape Coast: YACI Publishing House. (2015).

Asare-Danso, Seth, Nyarko Annobil, Charles Owusu Afriyie and Agyemang, Mary. Religious \& Moral Education: for Colleges of Education 1. Kumasi: Jerusalem Press. (2016)

Awuah, G. \& Afriyie, O. Religious and Moral Education II: Study of Content and Methodology. Kumasi UGC Publication House. (2006).

Ayers, E. L. Ethics in education. London: Prentice-Hall. (2009).

Debbarma, M. Importance of human values in the society. International Journal of English language, Literature, and Humanities. (2014).10: 193-223.

Dewey, J. Philosophy of education. New York: Horace Liveright. (1934).

Freud, S. Psychoanalytic theory. London: Hogarth Press. (1961).

Ganguli, H. C. Mehrotra, G. P. \& Mehlinger, H. D. "Values, Moral Education and Social Studies," In UNESCO Handbook for the Teaching of Social Studies. Edited by Harward D. Mehlinger. Paris: UNESCO. (1981).

Gelies, R. J. \& Levine, A. Sociology: An Introduction. (5th Ed.) New York: McGraw- Hill. (1995).

Goldman, R. Readiness for Religion. London: Routledge. (1965).

Gyekye, K. African Cultural Values. Accra: Sankofa Publishing Company. (1996),

Huitt, W. Values: Educational Psychology Interactive. Valdosta, GA: Valdosta State University. (2004).

Kankam, G. \& Onivehu, A. O. Principles and Practices and Practices of Guidance and Counseling. Accra: Accra Press. (2000).

Kirchenbaum, H. Advanced Values Clarification. La Jolla, CG: University Associates. (1977).

Kohlberg, L. Stages and Sequence: The Cognitive-developmental approach to socialization.” In D. A. Goslin

\footnotetext{
35 Sigmund Freud, .Psychoanalytic theory. 122.

36 George Kankam, \& A. O. Onivehu, Principles and Practices and Practices of Guidance and Counseling. 67.

37 R. Goldman, Readiness for Religion. London: Routledge (1965). 106.
} 
(Ed.), Handbook of Socialization Theory and research,(347 - 380). Chicago: Rand Mcnally. (1969). Kohlberg, L. The Psychology of Moral Development. (1984). San Francisco: Harper Row.

Lickona, Thomas, "The return of character education". NY: Bantam Doubleday. (1993).

Raths, L. E. Harmin, M. \& Simon, S. B. Values and Teaching. Columbus, Ohio: Merrill Publishing Co.

Skinner, Barrhus Frederick, Behavioural Theory. New York: Appleton. (1975).

Superka, D. Ahrens, C. \& Hedstrom. J. The values education life sourcebook. New York: Longman. (1976). 